\title{
CRETACEOUS FORAMINIFERA OF ARGENTINA: BIOGEOGRAPHIC TENDENCES
}

\author{
ALWINE BERTELS*
}

\begin{abstract}
During Cretaceous time, the Gondwana supercontinent palaeogeography suffered progressive changes which mainly controlled the benthonic Foraminifera distribution. In Argentina, the principal Cretaceous sedimentary basins are: Neuquén and Mendoza (plus Colorado in Maastrichtian time) and Magallanes. Neuquén and Mendoza basins. deposits are of Neocomian and Maastrichtian age. Neocomian. The assemblage shows biogeographic fluctuations; particularly in Berriasian, the low diversity is the reflect of the lack of stability of the western Argentina margin; from late Valanginian to Barremian the association is composed of wide distributed and/or cosmopolitan taxa. Maastrichtian. At the end of the Cretaceous in the Neuquén and Mendoza (plus Colorado) basins endemic taxa increase accompained by Northern hemisphere, bipolar distributed, species evolving into the Neuquén, Mendoza and Colorado Subprovince. Magallanes Basin. It is located at the southwestern extreme of South America. The provincial features changed in response to Cretaceous geologic, ecologic, and oceanographic history. Oxfordian-Barremian. Assemblages are composed of wide distributed and/or cosmopolitan, malagachian, and endemic taxa; gradually decreased endemism provides the basis for the inference of the Magallanes Subprovince in the Oxfordian-Hauterivian which evolved into a lower rank unit - Endemic Center - in the Barremian. Aptian-Albian. Specific diversity is low; a Province rank is attributed to the interval. Albian-Late Turonian. The income of australian taxa and the presence of endemics provide the basis for the Magallanes Province recognition. Coniacian-Campanian. Australian taxa increase whereas endemics decline; the Magallanes Province persisted untill this time. Maastrichtian. Widespread species of almost bipolar distribution characterizes the interval, accompanied by Austral Realm taxa; the provincial rank which persisted since Aptian times turned to the Magallanes Subprovince. Biogeographic comparison made between the Neuquén and Mendoza (plus Colorado in Maastrichtian time) and the Magallanes Basin benthonic Foraminifera shows sharp differences and strong provincial features; this fact is probably related to physical barriers (such as ridges and hights), ecological factors and plate tectonics.
\end{abstract}

RESUMO FORAMINÍFEROS CRETÁCEOS DA ARGENTINA: TENDÊNCIAS BIOGEOGRÁFICAS. Durante o Cretáceo, o supercontinente Gondwana experimentou sucessivas mudanças que controlaram a distribuiçăo dos foraminíferos bentônicos. As principais bacias sedimentares cretácicas argentinas sảo as de Neuquén e Mendoza (incluindo a de Colorado no Maastrichtiano) e de Magallanes. Bacias de Neuquén e Mendoza: Os depósitos marinhos sảo de idade neocomiana e maastrichtiảna. Neocomiano: A associação evidencia flutuaçôes biogeográficas; particularmente durante o Berriasiano a baixa diversidade reflete a instabilidade da margem ocidental argentina; a partir do Valanginiano até o Barremiano os conjuntos microfaunísticos estão compostos por taxa de ampla distribuiçăo e/ou cosmopolitas. Maastrichtiano: Ao final do Cretáceo, a bacia de Neuquén e Mendoza (incluindo a de Colorado) evidencia um aumento de espécies endêmicas acompanhadas por outras do hemisfério norte de distribuiçáo bipolar, evoluindo na Subprovíncia de Neuquén, Mendoza e Colorado. Bacia de Magallanes: Localizada no extremo sudoeste da América do Sul. As características provinciais se modificaram em resposta à história geológica, ecológica e oceanográfica. Oxfordiano-Barremiano: As associaçôes estão integradas por espécies de ampla distribuiçāo geográfica e/ou cosmopolitas, da República Malgasch (ex-Madagáscar) e endêmicas; uma diminuição gradual do endemismo fornece a base para a inferência da existência da Subprovíncia de Magallanes em tempos oxfordianos-hauterivianos que evoluíram até uma entidade de amplitude menor - Centro Endêmico - durante o Barremiano. Aptiano-Albiano: A diversidade é baixa; a amplitude da província é atribuída ao referido intervalo. Albiano-Neo-Turoniano: A presença de taxa australianos e endêmicos dá suporte para o reconhecimento da Província de Magallanes. Coniaciano-Campaniano: Os taxa australianos aumentam enquanto os endêmicos diminuem; a Província de Magallanes persistiu até este intervalo de tempo. Maastrichtiano: Espécies de ampla distribuição, quase bipolar, caracterizam o intervalo acompanhadas por taxa de domínio austral; a amplitude provincial que persistiu desde o Albiano se transformou na Subprovíncia de Magallanes. A comparação biogeográfica entre os foraminíferos bentônicos das bacias de Neuquén e Mendoza (incluindo a de Colorado durante o Maastrichtiano) e a de Magallanes mostra grandes diferenças e marcantes características provinciais; este fato está provavelmente relacionado a barreiras físicas (tais como dorsais e altos), fatores ecológicos e tectônica de placas.

INTRODUCTION The existence on the earth surface of biogeographic units based on several living organic groups is a fact clearly recognized in present times; the biotic differentiation is observed on terrestrial environments as well as in the marine ones. The causes which originate the faunal segregation are multiple and their interrelations complex, being the most important: a. ecological factors, such as temperature, salinity, $\mathrm{pH}$, oxigen, substrate, food disponibility, nutrients, calcium carbonate, and microelements; b. physical, in particular land barriers and ocean deeps which impede the free dispertion of organisms and cause their isolation; c. geodinamical, such as sea floor spreading and continental drift, and d. oceanographic, in particular deep water masses and surficial currents. They are responsible - in a large extend - for the outling of bioentities and their fluctuations.
The purpose of this paper is to determine the Argentina Cretaceous marine patterns of biogeographic units based on benthonic Foraminifera species.

Most authors (Kauffman 1973) use the generic or subgeneric taxonomic level for paleobiogeographic inferences. Analysing Foraminifera, species are more reliable for the obtention of objective quantitative results in the definition of biogeographic units and their evolution, since genera and subgenera are mostly wide distributed geographically and tend to show a great tendence toward cosmopolitism.

In Argentina, such its occurs in other areas, biogeographic tendences show a changing picture along the Cretaceous, as a result of the natural history of the region.

In early Cretaceous (Berriasian-Albian) times, the distribution of marine and continental areas was markedly 
different than in the Recent (Fig. 1). In the southern hemisphere, South America, Africa, Antarctica, Australia, Madagascar and India stand physically united or more proximal forming the Gondwana supercontinent which occupied latitudinal positions different than those of today.

The Tethys sea covered geographic areas approximately equivalent to the present Mediterranean and Caribbean united, although of larger dimentions; to the west and east it was communicated with the remainder marine water masses. Southernwards a southern proto Atlantic ocean and an incipient southwestern Indic Ocean invaded freely African and South American meridional areas; in the Southern hemisphaere these incipient oceans constituted the geographic dispersal way of several biologic groups, among others, the benthonic Foraminifera.

In late Cretaceous (Cenomanian-Maastrichtian) time (Fig. 2), beside other significant palaeogeographic modifications, the interval is essentially characterized by continuous Atlantic spreading, segregation of the Gondwana supercontinent and the consequent free communication between the North and South Atlantic oceans, changes in paleocirculation pattern and new migratory ways, among other important effects.

METHODS In order to analyze Argentina foraminiferal assemblages, their palaeobiogeographic features and the evolution during the Cretaceous, the available taxonomic information is listed and the assemblages compared with those of other regions.

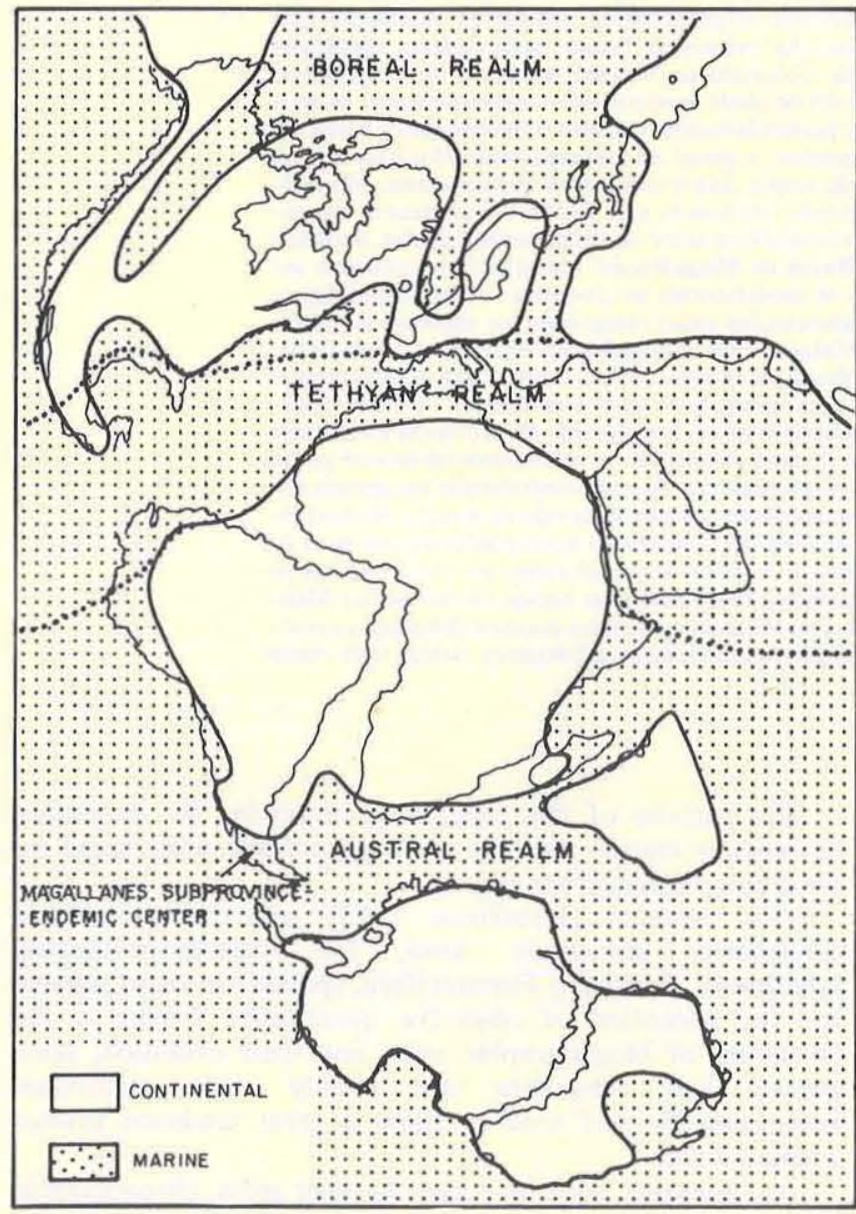

Figure 1 - Distribution of land and sea areas in the Early Cretaceous (Berriasian-Barremian) (in part after Tedford, 1974). In Argentina the Neuquén and Mendoza basin benthonic foraminiferal assemblage is of wide geographic distribution; the Megallanes assemblage is representive of a Subprovince (Oxfordian-Hauterivian) and an Endemic Center (Barremian).
Taxonomic determinations made by several authors are used in their original sense; no attempt is made for taxonomic modifications. With the finality to incorporate the largest number of species as possible, the following criteria have been adopted: a. species which are classified only at the generic level are ignored; b. those taxa introduced in the literature as $c f$. or aff. are interpreted to belong to the taxonomic unit with which they are compared of show affinities; c. species classified with a question mark (?) are asigned to the taxon; $\mathbf{d}$. subspecies are considered as species.

For the obtention of quantitative results, the criteria proposed by Simpson (1943), Johnson (1971) and Kauffman (1973) are used.

Simpson Coefficient is given by the formula (Simpson 1943):

$$
\mathrm{SC}=\frac{\mathrm{C}}{\mathrm{N}_{1}} \cdot 100
$$

Johnson (1972) Provincial Index equation is:

where:

$$
\mathrm{PI}=\frac{\mathrm{C}}{2 \mathrm{E}_{1}}
$$

$\mathrm{SC}=$ Simpson Coefficient

PI $=$ Provincial Index

$\mathrm{C}=$ Number of common species to both compared areas

$\mathrm{N}_{1}=$ Total number of species of the smaller population

$\mathrm{E}_{1}^{1}=$ Number of endemic taxa in the area under consideration

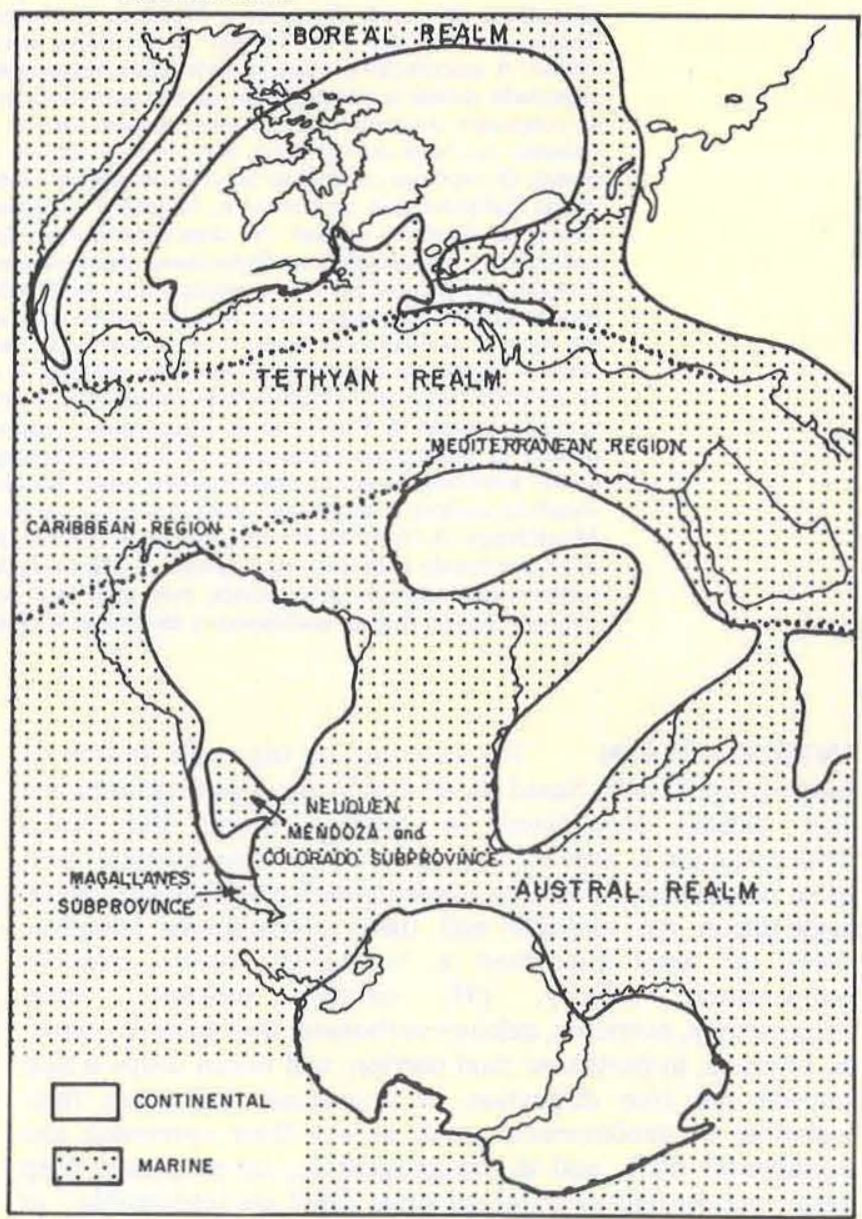

Figure 2 - Distribution of land and sea in the Late (retacens. (Maastrichtian) (in part after Tedford, 1974). In Argentina the Neuquén and Mendoza (+ Colorado) basins assemblage, of bipolar distribution and endemics, denote a Subprovince; in the Magallanes basin the homonymous Subprovince is recognized. 
Kauffman (op. cit.) proposed the differentiation of Cretaceous biogeographic units having into account the degree of endemism in a given area; these are: a. Endemic Center, with $5-10 \%$ of endemic genera; b. Subprovince 10-15\%; c. Province 25-50\%; d. Region 50-75\% and Realm $>75 \%$ of endemic genera.

Using Simpson Coefficient, values higher than 60 indicate cosmopolitism and minor endemism. Applying Johnson Provincial Index values minor than 1 satisfy provincial conditions; higher values coincide with cosmopolitan situations.

In several figures, the Argentina recorded taxa are listed according to their stratigraphic range and basin occurrence; in these lists, asterisk $\left(^{*}\right)$ indicate the geographic occurrence of the species as follows:

* Afromalgachian species

** Australian species

*** Endemic species

Taxa classified at the specific level with no asterisk are of wide geographic distribution.

The outlining of paleobiogeographic units are calculated quantitatively having into account the total endemic taxa in regional space and time.

CRETACEOUS MARINE SEDIMENTARY BASINS OF ARGENTINA Late Malm or Araucanian tectonic movements modified substantially the distribution of erosive areas and depositional centers; the previous behaviour of the southernmost extreme of South America had a cratonic or quasi cratonic character (Urien et al. 1981).

The basins in which early Cretaceous marine sedimentation is registered are: a. Neuquén and Mendoza, and b. Magallanes.

During late Cretaceous time, sea level changes allowed the

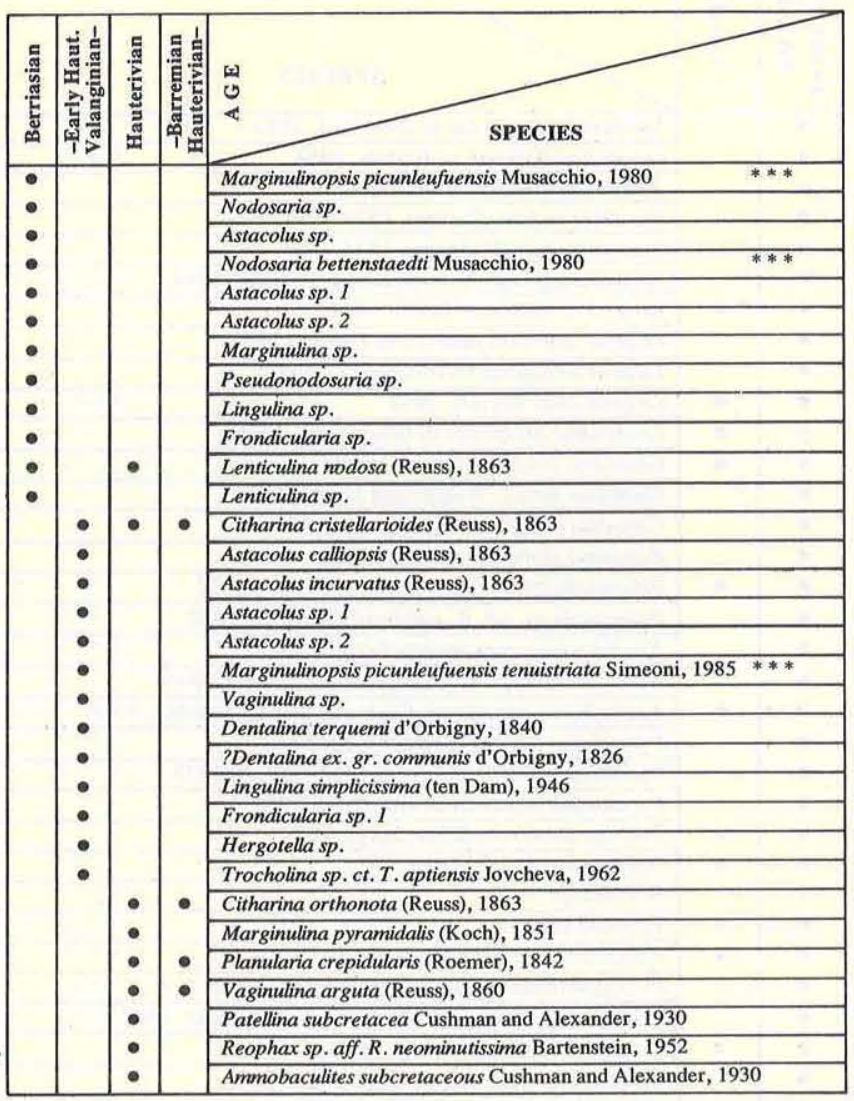

Figure $3 a$ - Stratigraphic distribution of Early Cretaceous (Berriasian-Barremian) benthonic Foraminifera in the Neuquén and Mendoza basin ingressions in the areas: a. Sierras Subandinas-Cordillera Oriental; b. Neuquén and Mendoza and Colorado basins, which were united at the end of the Cretaceous; and c. Magallanes basin.

Sierras Subandinas - Cordillera Oriental Late Cretaceous deposits are of marginal nature; foraminiferal microfaunas are extremely poor.

The only Foraminifera cited belong to the genera Discorbis, Valvulineria, Lingulogavelinella, Oritostella, and Bilingulogavelinella of Senonian age (Méndez \& Viviers 1973) and Miliolinella of Maastrichtian age (Kielbowicz \& Angelozzi 1984).

Due to the scaese micropaleontological material it is not possible to realize an quantitative faunal analysis.

Neuquén and Mendoza Basins (Figs. 3a-c, $4 a-b)$ Marine sedimentation is registered since the Jürassic. During early Cretaceous (Berriasian-Barremian), a succession of lithostratigraphic units were deposited; the nature of this deposits is preponderantely marine and probably - in a large part - of restricted environment.

During the ?Albian-?Campanian interval marine sedimentation was interrupted; only in the Maastrichtian a new high sea level stand is registered.

The late Cretaceous Intersenonian tectonic movements produced a change in the regional slope; with this event the first neatly atlantic ingression took place in the basin. During Maastrichtian time, the Neuquén and Mendoza and Colorado basins stand united. Marine and in some cases polihaline deposits were preceeded by a marked subsidence, particularly in areas of the present day Colorado and Negro rivers courses, accompanied by a sedimentation of continental aquatic environment, probably lagoons, marhes etc.

Figure $3 b$ - Stratigraphic distribution of Early Cretaceous (Berriasian-Barremian) benthonic Foraminifera in the Neuquén and Mendoza basin (cont.) 


\begin{tabular}{|c|c|c|c|c|}
\hline 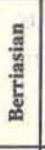 & 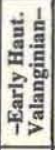 & 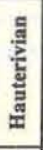 & 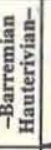 & $\begin{array}{l}\text { 엥 } \\
0 \\
4\end{array}$ \\
\hline & & \multirow{28}{*}{$\begin{array}{l}\bullet \\
\vdots \\
: \\
\vdots \\
\vdots \\
\bullet \\
\bullet \\
\bullet \\
\bullet\end{array}$} & & Cyclogyra sp. \\
\hline & $:$ & & & Wellmanella?sp. \\
\hline & & & & Miliammina sp. \\
\hline & & & & Dentalina sp. cf. D. communis d'Orbigny, 1826 \\
\hline & & & & Maeginulina sp. 1 \\
\hline & & & & Marginulina sp. 2 \\
\hline & & & he & Spirofrondicularia frondicularioides (Chapman), 1984 \\
\hline & & & & Lingulina sp. \\
\hline & & & & Globulina sp. \\
\hline & & & & Pyrulinoides? sp. \\
\hline & & & & Glandulopleurostomella? sp. \\
\hline & & & & Pseudopolymorphina sp. cf.P.roanokoensis Tappan, 1943 \\
\hline & & & & Epistomina sp. \\
\hline & & & & Astacolus sp.cf.A.calliopsis (Reuss), 1863 \\
\hline & & & - & Planularia madagascariensis Espitalié and Sigal, 1963 \\
\hline & & & - & Lenticulina ambanjabensis Espitalié and Sigal, 1963 \\
\hline & & & - & Marssonnella sp. \\
\hline & & & - & Miliammina sp. \\
\hline & & & - & Cyclogyra sp. \\
\hline & & & - & Pseudonodosaria sp. \\
\hline & & & - & Astacolus sp. \\
\hline & & & - & Lenticulina sp. \\
\hline & & & - & Tristix sp. \\
\hline & & & - & Marginulina sp. \\
\hline & & & - & Epistomina sp. \\
\hline & & & - & Pyrulina sp. \\
\hline & & & - & Eoguttulina sp. \\
\hline & & & - & Conorboides sp. \\
\hline
\end{tabular}

Figure $3 c$ - Stratigraphic distribution of Early cretaceous (Berriasian-Barremian) benthonic Foraminifera in the Neuquén and Mendoza basin (cont.)

BERRIASIAN-BARREMIAN Assemblages from the interval were studied by Musacchio $(1979,1980)$ and Simeoni (1985). Figures 3a-c list the recorded taxa; figure 5 synthetizes the obtained values, such as number of taxa, endemics, wide distributed or peculiar from the Austral Realm. Results concerning the Provincial Index (Johnson 1971), Simpson Coefficient (Simpson 1943), and the percent of endemic taxa (Kauffman 1973) of the basin are tabulated and plotted in figures 6,7 , and 8 , respectively.

The Berriasian is characterized by low diversity, with atypical provincial values probably do to tectonic features, in particular the lack of stability of the basin which influenced the environmental conditions.

The late Valanginian-Barremian interval is characterized by the participation in the community of species of wide geographic, almost cosmopolitan distribution. Most taxa are widely recorded, being important to mention northern Europe (Reuss 1863, Chapman 1891-1898) and Trinidad (Bartenstein et al. 1957, 1966, Bartenstein \& Bolli 1973, 1977). Only one endemic species is registered; two were previously recorded from Madagascar by Espitalié \& Sigal (1963).

MAASTRICHTIAN (Figs. 4a-b; 5, 6, 7 and 8) The deposits are widely distributed in the basin; their faunal content was studied by Bertels $(1972,1980)$ and Kielbowicz (1980). A large part of the assemblage was described originally from northern Europe (Reuss 1850, Brotzen 1936) and the Gulf and atlantic coast of the United States (Jennings 1936, Carsey 1926, Olsson 1960). Only one is assimilable to the Australian faunas and (10) are endemic.

Besides the endemic taxa, the principal feature of the association is the bipolar distribution; the latitudinal dispersal lost their cosmopolitan or wide distributed character such it was evident in early Cretaceous times. The Subprovince of
Neuquén, Mendoza and Colorado is recognized.

PALAEOBIOGEOGRAPHIC TENDENCES IN THE NEUQUÉN AND MENDOZA (PLUS COLORADO IN THE MAASTRICHTIAN) BASINS During early Cretaceous time, the South American and African continents stand united or very close; climates were more uniform and latitudinal thermal gradients lesser than today; in marine areas the paleotemperature belts were much broader and gradational than in recent times. The marine current designs probably followed and approximately circumcontinental model. This hypothesis is supported by the fact of the practically cosmopolitan or wide distributed biota, although large Realms are differentiated: the Tethyan owing to the participation in the associations of large Foraminifera which - in analogy with the actual representatives - principally require warm water for their existence, the Boreal and the Austral.

The Neuquén and Mendoza basins early Cretaceous (Berriasian-Barremian) microfauna is composed by wide geographic distributed almost cosmopolitan taxa; no provincial features can be distinguished.

During late Cretaceous time, the latitudinal distribution of microfaunas lost their accentuated cosmopolitan, or wide distributed features, such as occurred earlier. The paleogeography is modified: South America is separated from Africa approximately $50-75 \%$ with respect to the present (Berggren \& Phillips 1971). As a consequence of continental migration, changes in the marine circulation pattern were

\begin{tabular}{|c|c|c|}
\hline 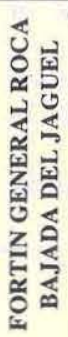 & 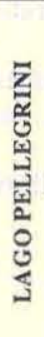 & $\frac{2}{3}$ \\
\hline \multirow{9}{*}{$\begin{array}{l}: \\
\vdots \\
\vdots \\
\bullet\end{array}$} & \multirow{9}{*}{$\bullet$} & Spiroplectammina laevis (Roemer), 1840 \\
\hline & & Gaudryina boltovskoyi Bertels, 1964 \\
\hline & & Tritaxia pyramidata Reuss, 1863 \\
\hline & & Dorothia bulleta (Carsey), 1926 \\
\hline & & Nodosaria marcki (Reuss), 1846 \\
\hline & & Nodosaria sp. aff. N. torsicostata ten Dam, 1944 \\
\hline & & Lagena acuticostata Reuss, 1863 \\
\hline & & Lagena amphora paucicosta Franke, 1928 \\
\hline & & Lagena hexagona (Williamsor), 1848 \\
\hline \multirow{2}{*}{ • } & \multirow{2}{*}{ • } & Lagena atilai Bertels, 1964 \\
\hline & & Lenticulina navarroensis (Plummer), 1926 \\
\hline \multirow{2}{*}{$\bullet$} & \multirow[t]{2}{*}{$\bullet$} & Globulina inaequalis Reuss, 1850 \\
\hline & & Guttulina lactea (Walker and Jacob), 1784 \\
\hline \multirow{2}{*}{$\bullet$} & \multirow{4}{*}{$\bullet$} & Guttulina problema d'Orbigny, 1826 \\
\hline & & Ramulina globulifera Brady, 1879 \\
\hline \multirow{2}{*}{ • } & & Buliminella pseudeolegantissima Bertels, 1972 \\
\hline & & Buliminella sp. aff. B. pulchra (Terquem), 1882 \\
\hline \multirow{4}{*}{ • } & \multirow{4}{*}{ - } & Neobulimina argentinensis Bertels, 1972 \\
\hline & & Neobulimina aspera (Cushman and Parker), 1940 \\
\hline & & Neobulimina canadensis Cushman and Wickenden, 1928 \\
\hline & & Pyramidina rugosa (Brotzen), 1945 \\
\hline \multirow{3}{*}{$\ddot{\bullet}$} & \multirow[b]{3}{*}{$\bullet$} & Pyramidina prolixa (Cushman and Parker), 1935 \\
\hline & & Pyramidina paleocenica (Brotzen), 1948 \\
\hline & & Bolivina decurrens (Ehrenberg), 1854 \\
\hline \multirow{3}{*}{ • } & \multirow[t]{2}{*}{ - } & Bolivina incrassata Reuss, 1851 \\
\hline & & Bolivina sp. \\
\hline & \multirow{2}{*}{ 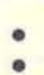 } & Tappanina? sp. \\
\hline \multirow{2}{*}{$\bullet$} & & Hiltermannella kochi (Bertels), 1970 \\
\hline & $\bullet$ & Praeglobobulimina jaguelensis Bertels, 1972 \\
\hline \multirow{2}{*}{$\bullet$} & \multirow{4}{*}{$\bullet$} & Pseudouvigerina sp. aff. P. cimbrica (Troelsen), 1937 \\
\hline & & Cassidella tegulata (Reuss), 1845 \\
\hline \multirow{2}{*}{$\bullet$} & & Coriphostoma plaita (Carsey), 1926 \\
\hline & & Stilostomella spinosa (Hofker), 1956 \\
\hline
\end{tabular}

Figure 4a-Maastrichtian Foraminifera of the Neuquén and Mendoza and Colorado basins 


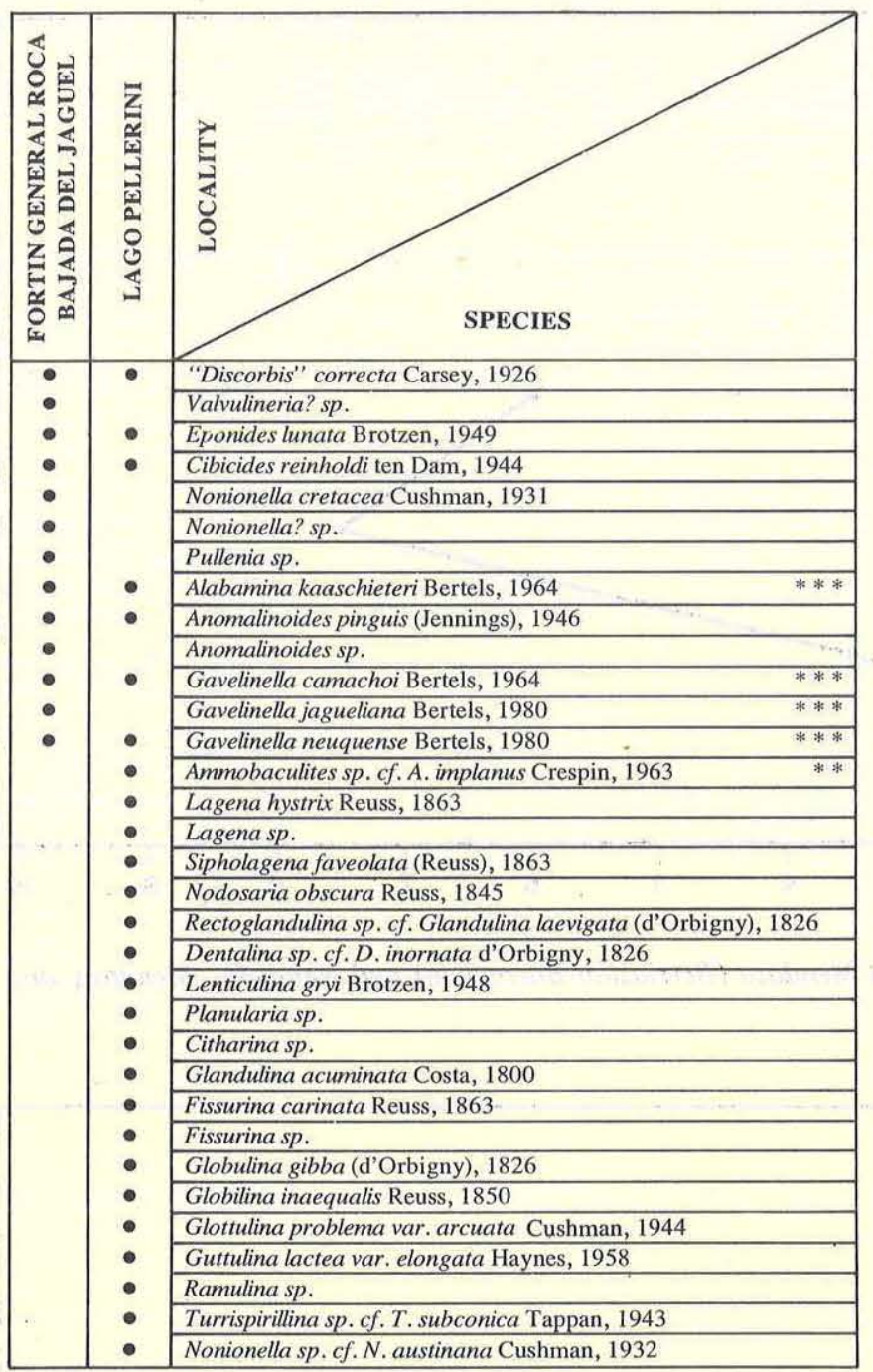

Figure $4 b$ - Maastrichtian foraminifera of the Neuquén and Mendoza Colorado basins (cont.)

introduced in the world's ocean as well as more pronounced latitudinal thermal gradients - than in early Cretaceous which also modified the distribution of benthonic Foraminifera. These facts incided in the biotic differentiation at late Cretaceous times, a fact which became much more accentuated during the Cenozoic owing to the paulatine climatic deterioration.

The Boreal; Tethyan, and Austral Realm are recognized; in late Cretaceous times, in the Tethyan Realm, the Caribbean and the Mediterranean regions are distinguished in spite of their own large Foraminifera.

In Argentina, toward the end of the Cretaceous the Neuquén Mendoza and Colorado Subprovince is outlined by means of the participation in the largest part of the assemblages of endemic and bipolar distributed taxa.

Magallanes Basins (Figs. 9a-d, 10a-c, 11, 12, 13 and 14) It is located in the austral extreme of South America; it was an eugeosincline of SW-NE trend with a sedimentary thickness of about $6,650 \mathrm{~m}$ accumulated during Mesozoic time (Urien et al. 1981).

The sedimentary cycle is intimately related to the Araucanian (Oxfordian) diastrophic movements; the deposits are post-orogenic and in many cases they show "flyschoid" features (Urien et al. op. cit.).

The stratigraphy and microfaunas are principally known from the Argentina-Chile Andes and from extraandean

\begin{tabular}{|c|c|c|c|c|c|c|c|c|c|c|}
\hline 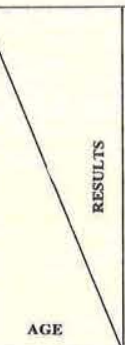 & 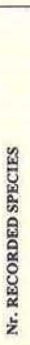 & 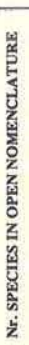 & 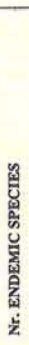 & 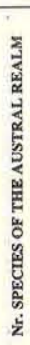 & 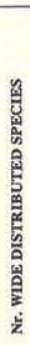 & 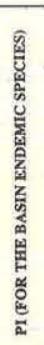 & 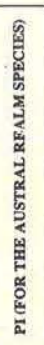 & 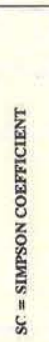 & 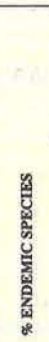 & 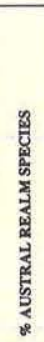 \\
\hline Maastrichtian & 66 & 11 & 10 & 11 & 37 & 1.85 & 1.68 & 67.27 & 18.18 & 20 \\
\hline $\begin{array}{l}\text {-Barremian } \\
\text { Hauterivian- }\end{array}$ & 25 & 12 & - & 1 & 12 & - & .6 & 92.30 & 0 & 8.33 \\
\hline Early Hauterivian & s5 & 23 & - & 2 & 30 & 0 & 7.5 & 92.75 & $=$ & 6.25 \\
\hline $\begin{array}{l}\text { Early Hauterivian } \\
\text { Late Valanginian- }\end{array}$ & 13 & 5 & 1 & 1 & 7 & 3.5 & 3.5 & 87.50 & 12.50 & 12.50 \\
\hline Berriasian & 12 & 9 & 2 & 2 & 1 & 0.25 & 0.25 & 33.33 & 66.66 & 66.66 \\
\hline
\end{tabular}

Figure 5 -Quantitative results obtained from the benthonic Foraminifera analysis of the Neuquén and Mendoza (Berriasian-Barremian) and Neuquén, Mendonza and Colorado (maastrichtian) basins

boreholes; they were investigated by Malumian (1968), Sigal et al. (1970), Malumian et al. (1971), Flores et al. (1974), Natland et al. (1974) Cañón \& Ernst (1974), Malumian \& Masiuk (1975, 1977), Kielbowicz et al. (1983), and Malumian \& Náñez (1983).

The chronostratigraphic correlation of the sedimentary succession is in general very broad, being difficult to conciliate the several authors criterion. The used discernment is explained in Bertels (1986). The analyzed intervals are shown in figures $9 \mathrm{a}-\mathrm{d}$ and $10 \mathrm{a}-\mathrm{c}$; the results in figures 11,12 , 13 and 14.

OXFORDIAN-BARREMIAN The main character is the presence of wide distributed and the participation of malgachian taxa, although northern hemisphere species surpass widely in number the Madagascar ones. In the Austral Realm the Malgachian Region is recognized; having into account the obtained values, but in particular the percentage of endemic taxa, the Magallanes Subprovince can be recognized for the Oxfordian-Hauterivian, whereas the decreasing of endemics indicate a lower rank unit - Endemic Center - for the Barremian.

APTIAN-ALBIAN The specific diversity is low; only 15 taxa are cited; nevertheless, the obtained values allow to infere provincial features for the interval. The absence of African and Australian species is remarkable; in the incipient South Atlantic, Scheibnerova (1978) noted Australian influences, whereas Sliter (1974) postulated for the regional faunas' provincial features, low temperatures, and restricted oceanic interchange.

ALBIAN-LATE TURONIAN The slow income of Australian species as well as the increase of edemic taxa is registered; the resting assemblage is composed by wide distributed species. Having into account all obtained quantitative results in the Austral Realm and the Malgachian Region the Magallanes Province is neatly differenciated (Fig. 12,13 and 14).

CONIACIAN-CAMPANIAN When compared with Albian-Late Turonian assemblages an increase of Austrabian taxa, proportional to the total community, as well as a diminution of endemic taxa, is registered. The obtained quantitative values (Figs. 12, 13 and 14), but particularly the percentage of endemics, reflect a similar trend than since Aptian times. 


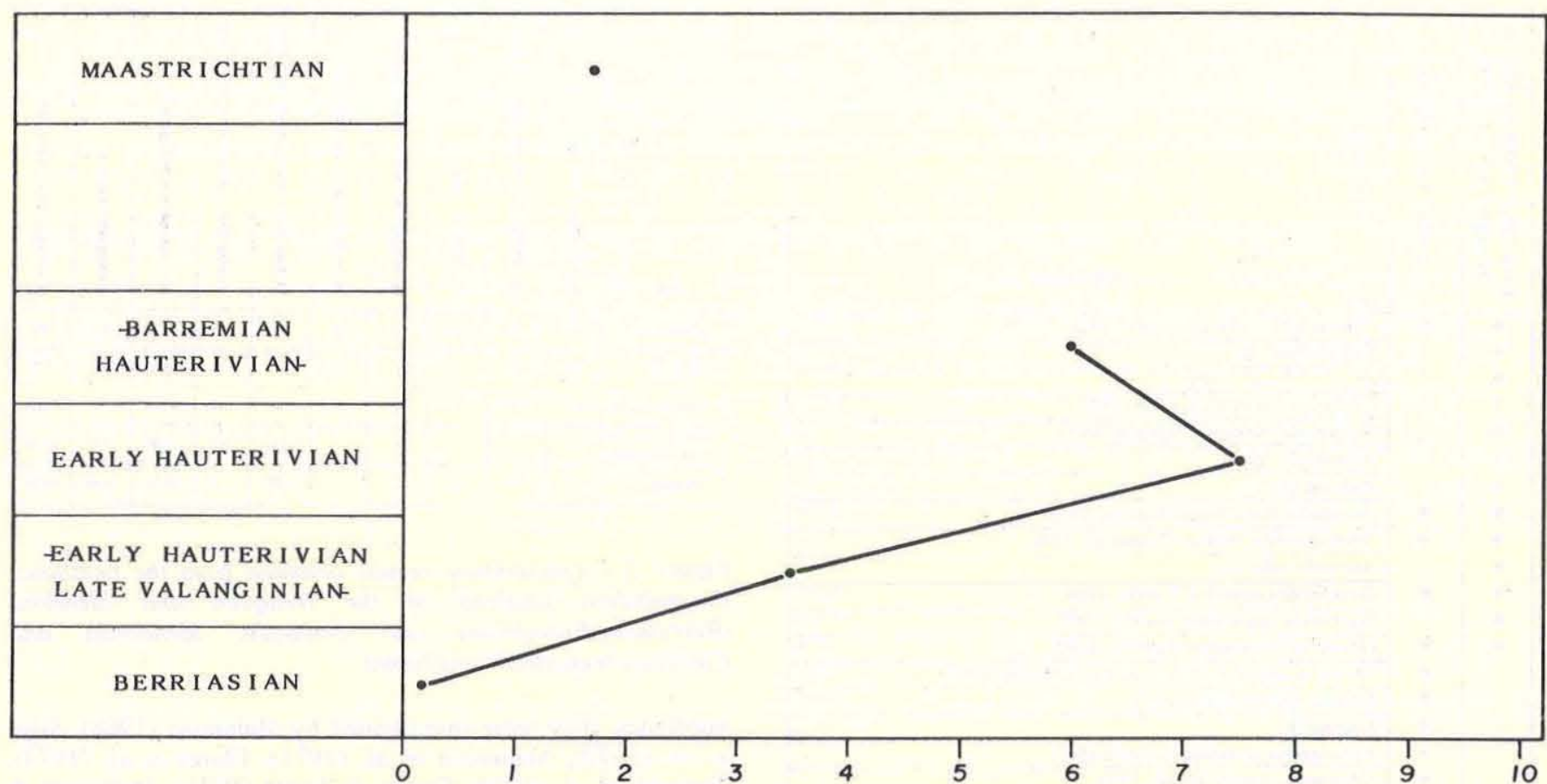

Figure 6 - Provincial Index plotted values for the Neuquén and Mendoza (Berriasian-Barremian) and Neuquén, . Mendoza and Colorado (Maastrichtian) basins (total austral species)

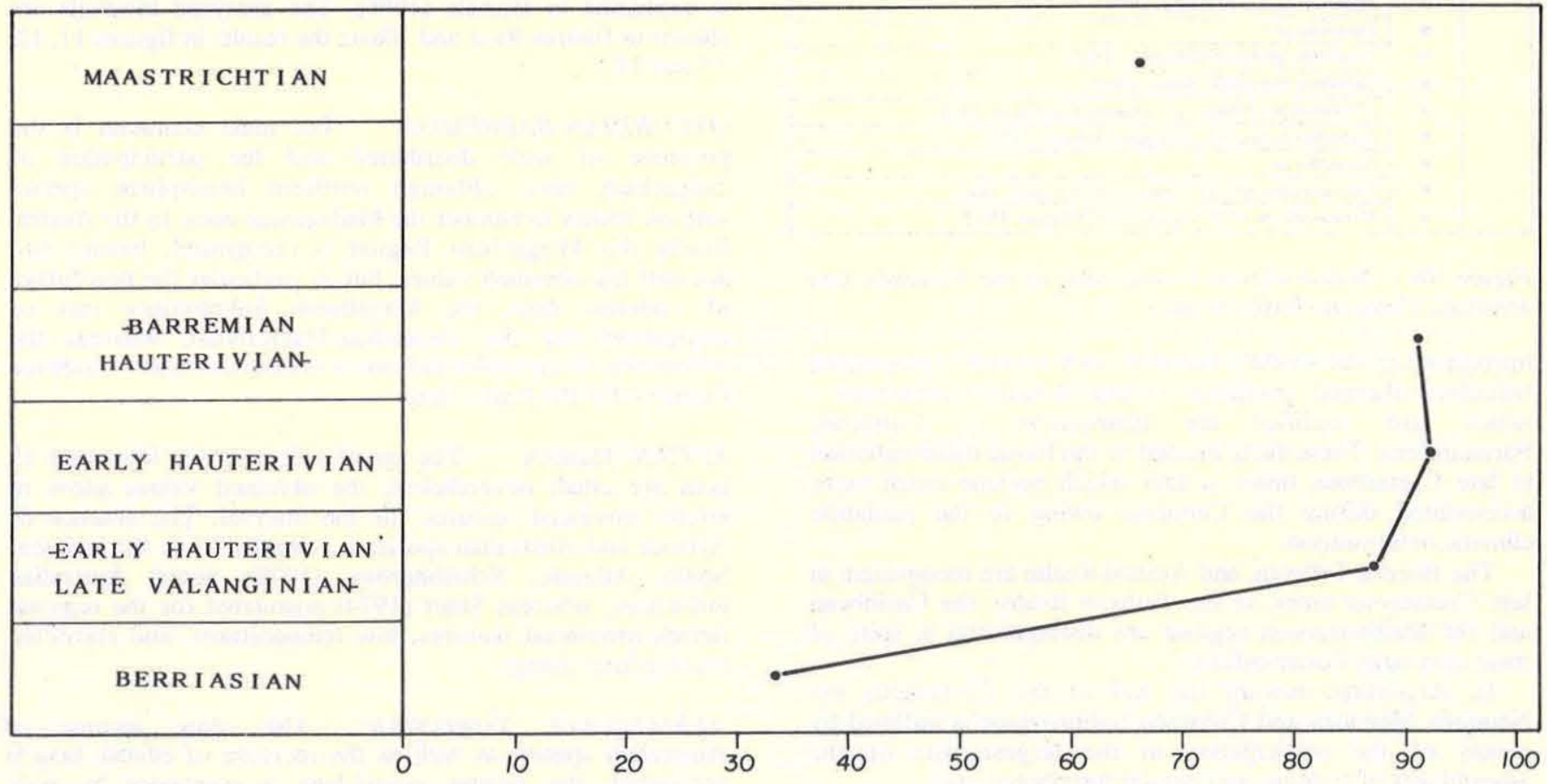

Figure 7 - Simpson Coefficient plotted values for the Neuquén and Mendoza (Berriasian-Barremian) and Neuquén, Mendoza and Colorado (Maastrichtian) basins

MAASTRICHTIAN All obtained quantitative data indicate cosmopolitan features for the time; nevertheless the bipolar distribution of the assemblages is remarkable, such it occurred since the beggining of the Late Cretaceous; only two taxa are endemic and 12 are restricted to the Austral Realm. The bipolar distribution contributes for the recognizon of the Magallanes Subprovince.
PALAEOBIOGEOGRAPHIC TENDENCES IN THE MAGALLANES BASIN The specific diversity, expressed in their simplest form (number of taxa), is always low, particularly when compared with the Boreal and Tethyan Realms benthonic Foraminifera assemblages. In the Magallanes Basin this fact is the result of several factors being the most important the evolutionary immaturity of the 


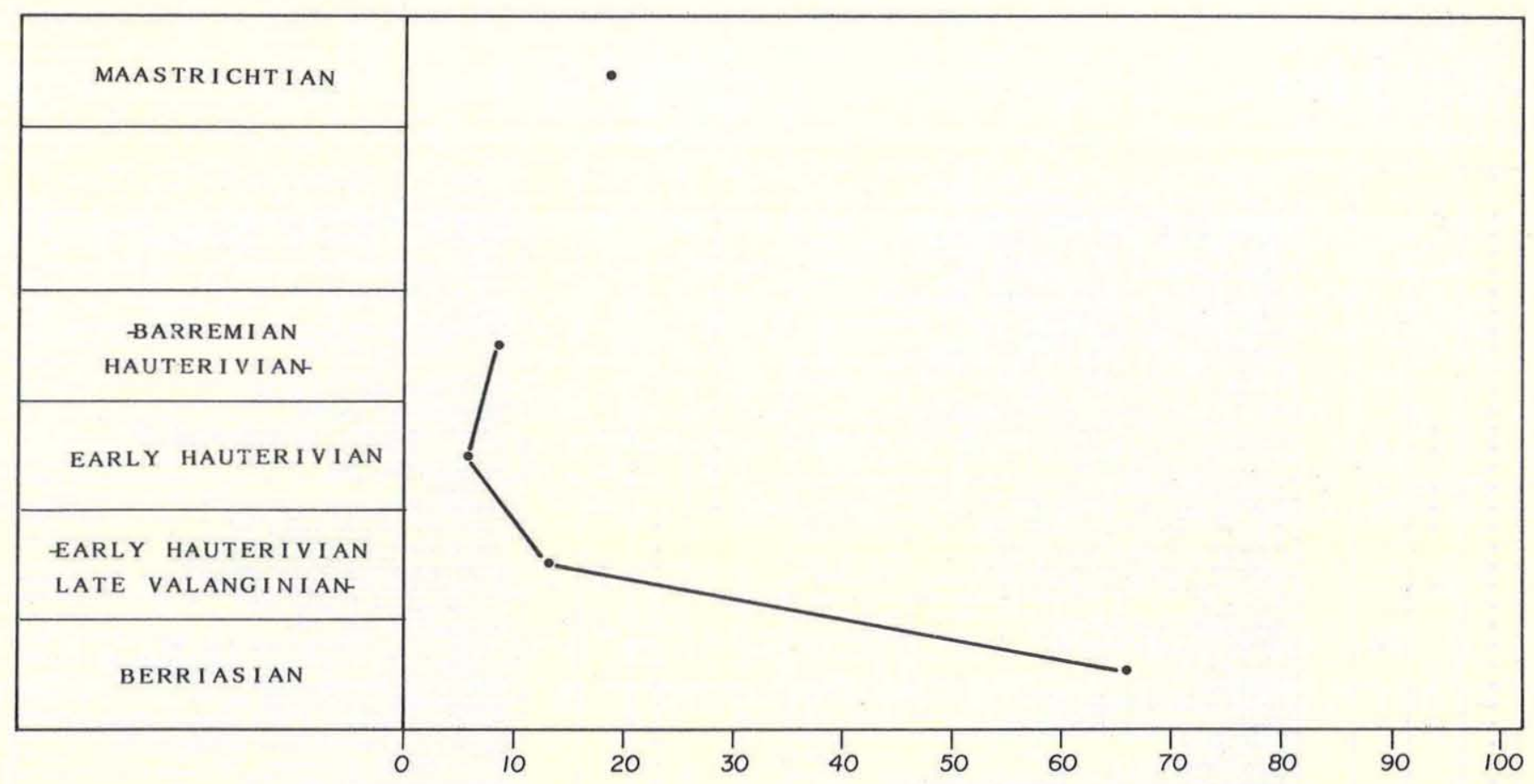

Figure 8 - Percentage of endemic taxa of the Neuquén and Mendoza (Berriasian-Barremian) and Neuquén, Mendoza and Colorado (Maastrichtian) basins (total austral species)

area, lack of tectonic stability, sedimentary conditions, existence of geographic barriers, preservation and in some geologic times the prevailing anoxic conditions in the proto South Atlantic.

During the Neocomian, the Magallanes Basin benthonic Foraminifera assemblage is peculiarized by the marked participation of afromalgachian elements ( $c f$. Espitalié \& Sigal 1963, McLachlan et al. 1976); nevertheless the malgachian participation, beside the endemics, the association has a remarkable contribution of wide distributed, almost cosmopolitan, taxa. The more uniform world marine ecologic conditions and lesser latitudinal thermal gradients allowed the dispersal of benthonic Foraminifera over wide marine areas and their life in all Realms.

In spite of the endemic taxa the Magallanes Subprovince is recognized for the Oxfordian-Hauterivian interval, whereas the decreasing of peculiar species in Barremian times provides quantitative data for the recognition of an Endemic Center.

The Aptian-Late Turonian interval, having into account all the obtained values, is characterized by a marked provincialism and small contribution of Australian taxa in Albian-Late Turonian times. Obviating the low diversity, the biogeographic feature is the result of the endemic species percentage; in the interval, the existence of the Magallanes Province is recognized, considering principally Kauffman (1973) proposed ranks.

At Turonian times, the North and South Atlantic intercommunication was deffinitively established and the free dispertion of organisms was feasible throughout this migratory way.

The microfauna of the Coniacian-Campanian is characterized by the participation , of some Australian elements and the presence of Foraminifera of essentially bipolar distribution. Johnson Provincial Index and Simpson Coefficient indicate values near the boundary of provincial-endemic situations, whereas the percent of endemics reflect provincial rank; thus the Magallanes Province persisted since Aptian time.
In Maastrichtian time, endemic species percentage reduce slowly as well as the participation of Australian elements; this fact is directly related to the increment of preferentely bipolar distributed taxa; although the quantitative results indicate cosmopolitan situation, the bipolar features of the benthonic Foraminifera indicate the existence of the Magallanes Subprovince. In the basin it is remarkable the decline in rank in the Late Cretaceous.

At the end of the Cretaceous, the palaeogeographic features in the South Atlantic differed markedly from those of Early Cretaceous times; sea floor spreading and continental drift influenced greatly in the South Atlantic natural history. This fact brought progressive changes in the circulation pattern which probably lead to the decrease of water temperatures and a more prominent marine climatic zonation, which restricted the geographic distribution of benthonic Foraminifera to some climatic belts, giving rise to bipolar distributions such is the case in the basin.

COMPARISON BETWEEN THE ASSOCIATIONS OF THE NEUQUÉN AND MENDOZA (+ COLORADO) AND MAGALLANES BASINS Early Cretaceous (Berriasian-Barremian) assemblage which colonized the Neuquén and Mendoza and Magallanes basins allow to infere several differences between both microfaunistic communities for same chronostratigraphic intervals.

For the considered time, (42) valid species are known from the Neuquén and Mendoza basins whereas (47) valid taxa were recorded from the Magallanes Basin; the minor association is that of the Neuquen and Mendoza basin.

Common species to both basins, mentioned untill the present, are only nine: Planularia madagascariensis Espitalié \& Sigal, Lenticulina (L.) nodosa nodosa (Reuss), Saracenaria tsaramandrosoensis Espitalié \& Sigal, Lenticulina sp. cf. L. subtilis (Wisniowski), Lenticulina crepidularis (Roemer), Eoguttulina sp. cf. E. anglica Cushman \& Ozawa, Nodosaria fontannesi (Berthelin), Dentalina linearis (Roemer), and Lingulina nodosaria Reuss. 


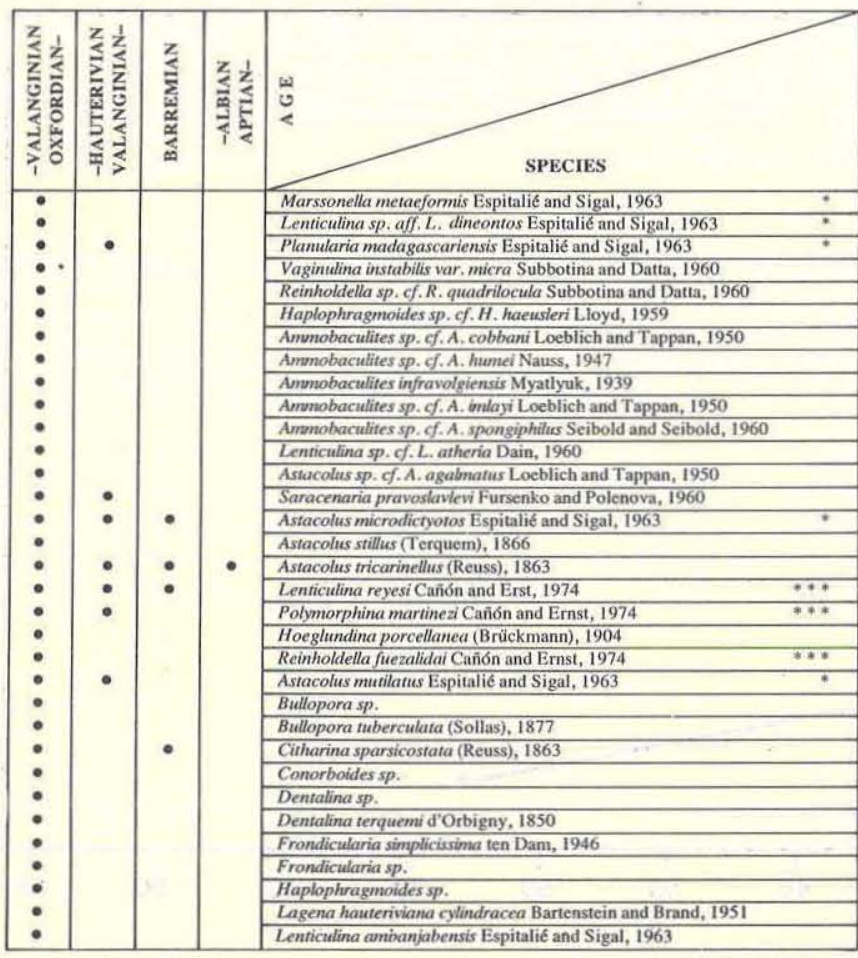

Figure 9a - Stratigraphic distribution of Early Cretaceous benthonic Foraminifera in the Magallanes Basin.

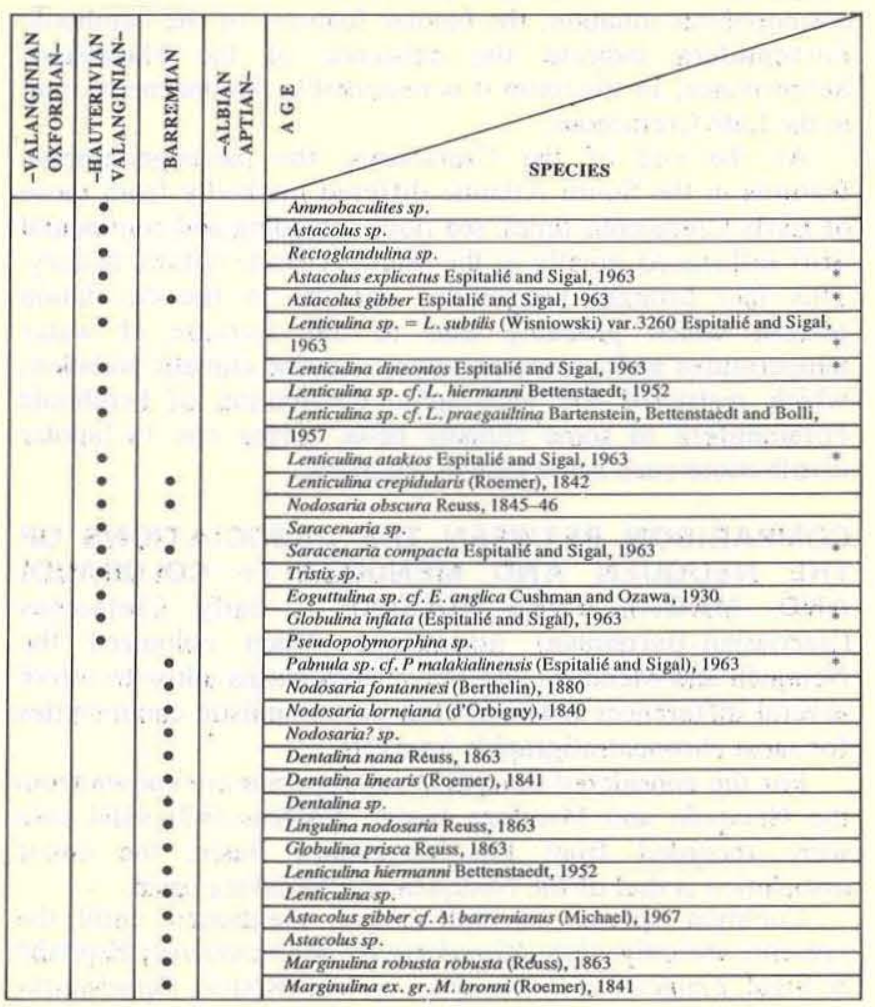

Figure 9c - Stratigraphic distribution of Early Cretaceous benthonic Foraminifera in the Magallanes Basin (cont.)

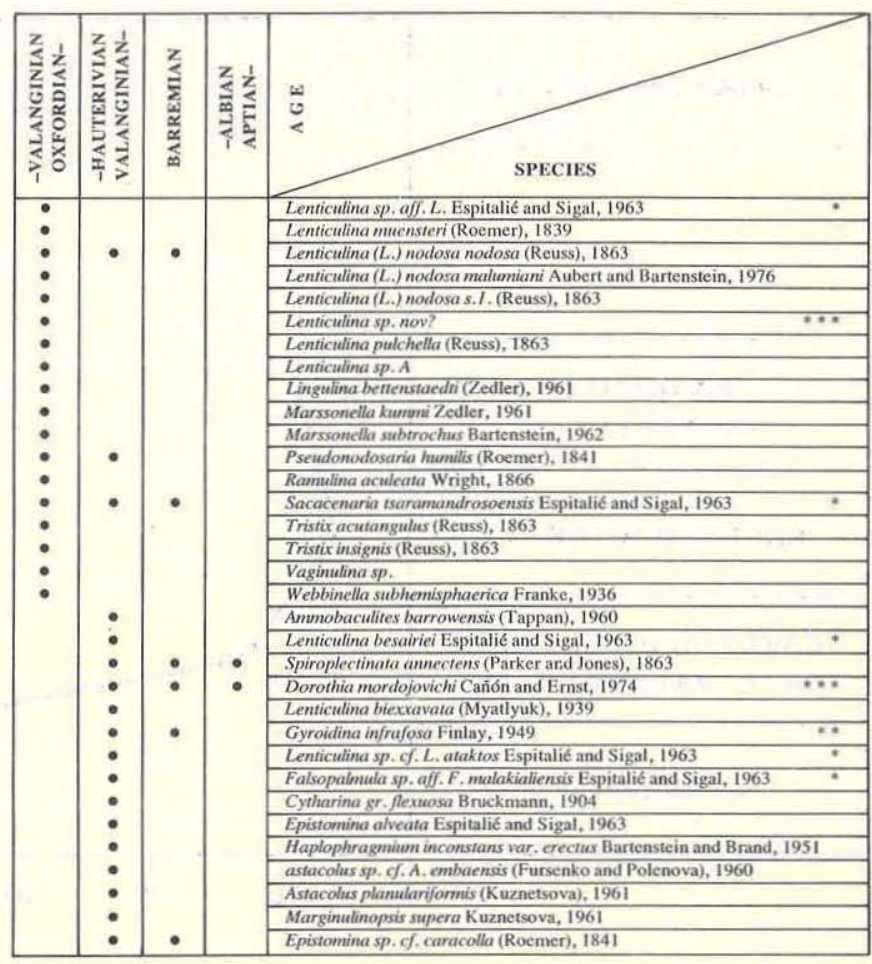

Figure $9 b$ - Stratigraphic distribution of Early Cretaceous benthonic Foraminifera in the Magallanes Basin (cont.)

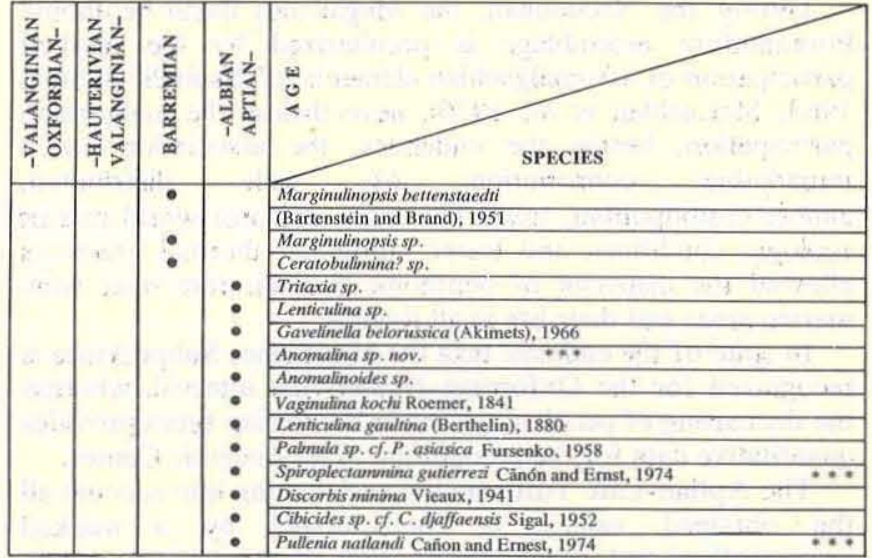

Figure $9 d$ - Stratigraphic distribution of Early Cretaceous benthonic Foraminifera in the Magallanes Basin (cont.)

Applying formulae which conduce to the numerical expression of provincialism such as the Provincial Index and Simpson Coefficient, the following results are obtained:

$$
\mathrm{PI}=0.13 \quad \mathrm{SC}=21.42
$$

values which indicate clearly the different behaviour and the remarkable provincial situation of both basins. The obtained data reflect some interesting aspects: 


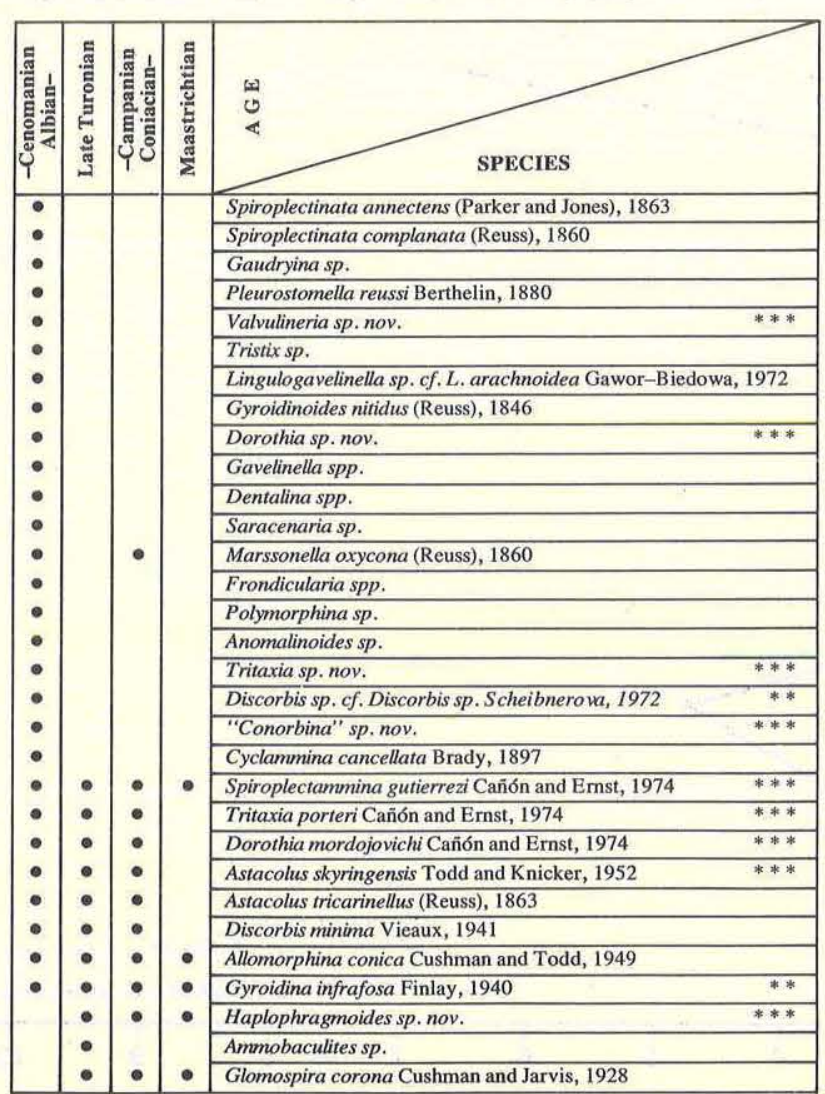

Figure 10a - Stratigraphic distribution of Late C'retaceous benthonic Foraminifera in the Magallanes basin

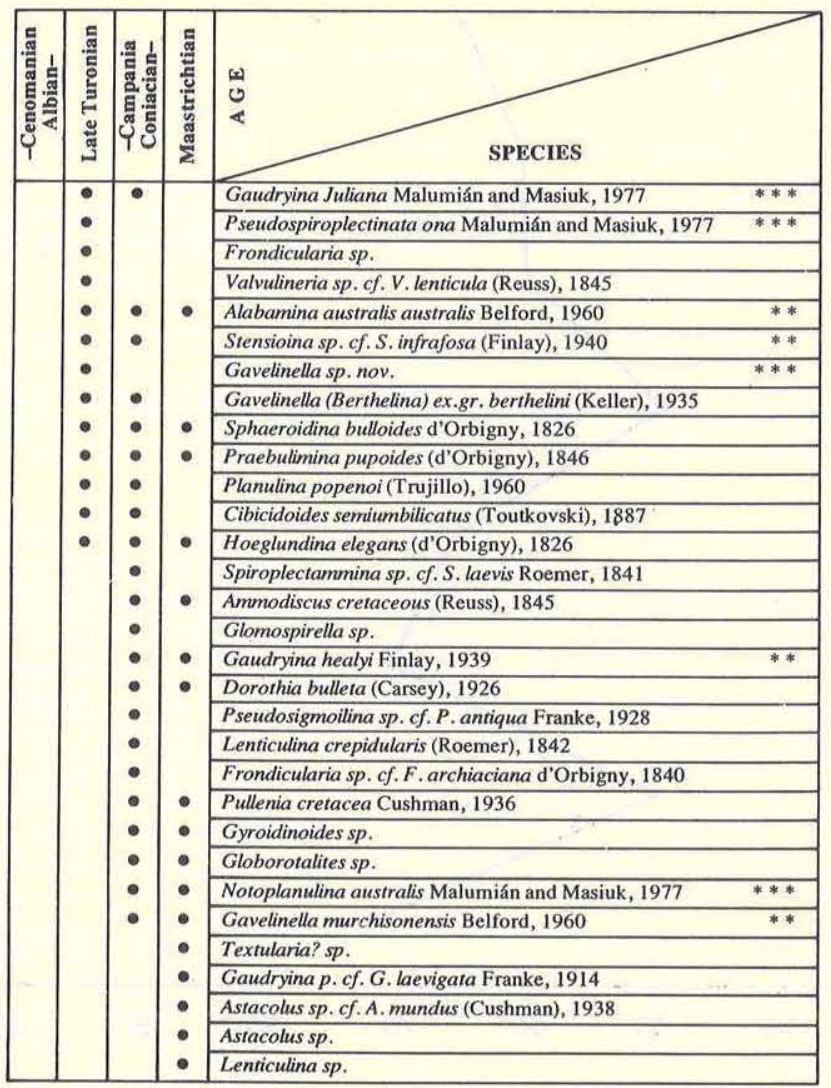

Figure $10 b$ - Stratigraphic distribution of Late Cretaceous benthonic Furaminifera in the Magallanes hasin (cont.)

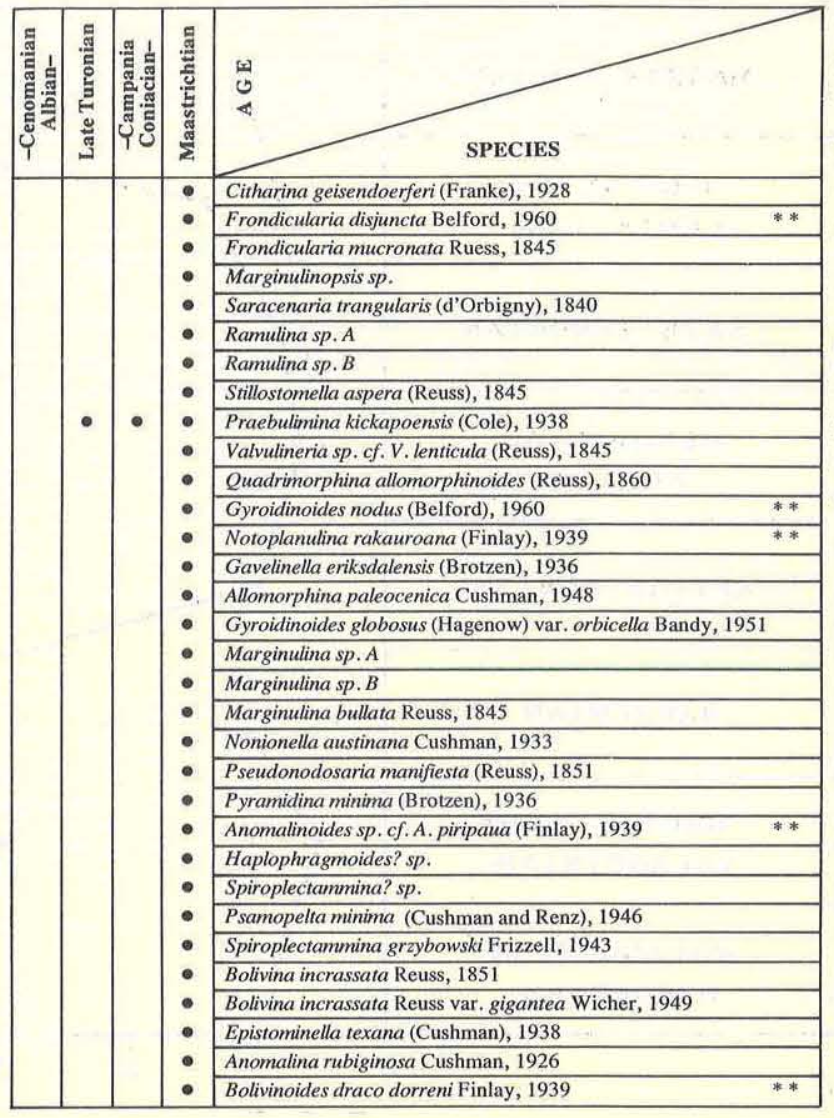

Figure 10c - Stratigraphic distribution of Late Cretaceous benthonic Foraminifera in the Magallanes basin (cont.)

\begin{tabular}{|c|c|c|c|c|c|c|c|c|c|c|}
\hline $\int^{\frac{n}{2}}$ & 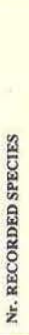 & 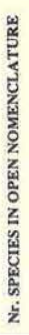 & 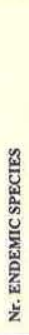 & 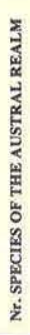 & 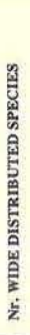 & 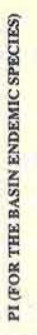 & 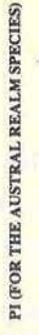 & 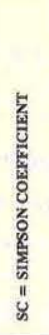 & 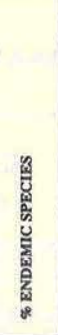 & 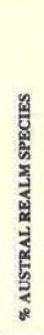 \\
\hline Maastrichtian & 54 & 12 & 2 & 12 & 28 & 7 & 1.16 & 66.66 & 4.74 & 28.57 \\
\hline $\begin{array}{l}\text {-Campanian } \\
\text { Coniacian- }\end{array}$ & 34 & 3 & 7 & 12 & 19 & 1.35 & 0.79 & 61.29 & 22.58 & 38.70 \\
\hline Late Turonian & 25 & 2 & 8 & 11 & 14 & 0.87 & 0.63 & 60.87 & 34.78 & 47.82 \\
\hline $\begin{array}{l}\text {-Cenomanian } \\
\text { Albian- }\end{array}$ & 28 & 8 & 8 & 10 & 10 & 0.62 & 0.50 & so & 40 & 50 \\
\hline Aptian - Albian & 15 & 3 & 4 & 4 & 8 & 1 & - & 66.66 & 33.33 & - \\
\hline Barremian & 33 & 6 & 2 & 8 & 19 & 4.75 & 1.18 & 70.37 & 7.47 & 29.62 \\
\hline $\begin{array}{l}\text {-Hauterivian } \\
\text { Valanginian- }\end{array}$ & 41 & 6 & 3 & 17 & 18 & 3 & 0.52 & 51.42 & 8.47 & 48.57 \\
\hline $\begin{array}{l}\text {-Valanginian } \\
\text { Oxfordian- }\end{array}$ & 51 & 7 & 5 & 12 & 32 & 3.20 & 0.94 & 72.72 & 11.36 & 38.63 \\
\hline
\end{tabular}

Figure 11 - Quantitative results obtained from the benthonic Foraminifera analysis of the Magallanes basin

1. During a large part of the Neocomian, between both basins, an important barrier existed on the occidental margin of the continent which did not allow the free. migration of organisms; the barrier could probably be represented by a similar to the present Chile ridge.

2. The existence of climatic belts, which could affect the faunal distribution, is rejected; evaluating each faunal assemblage separately, the taxa present in both basins have 


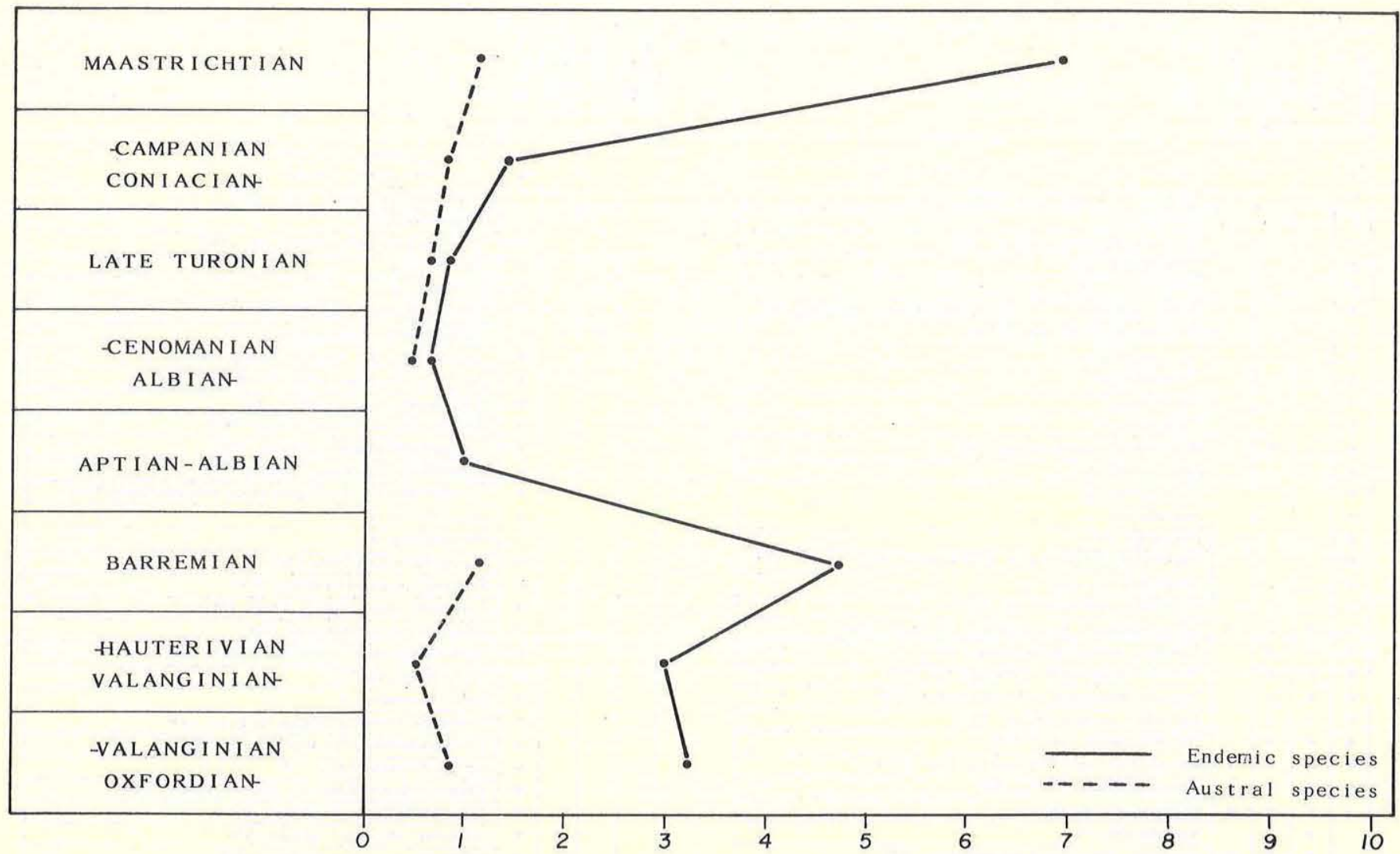

Figure 12 - Provincial Index plotted values for the Magallanes Basin

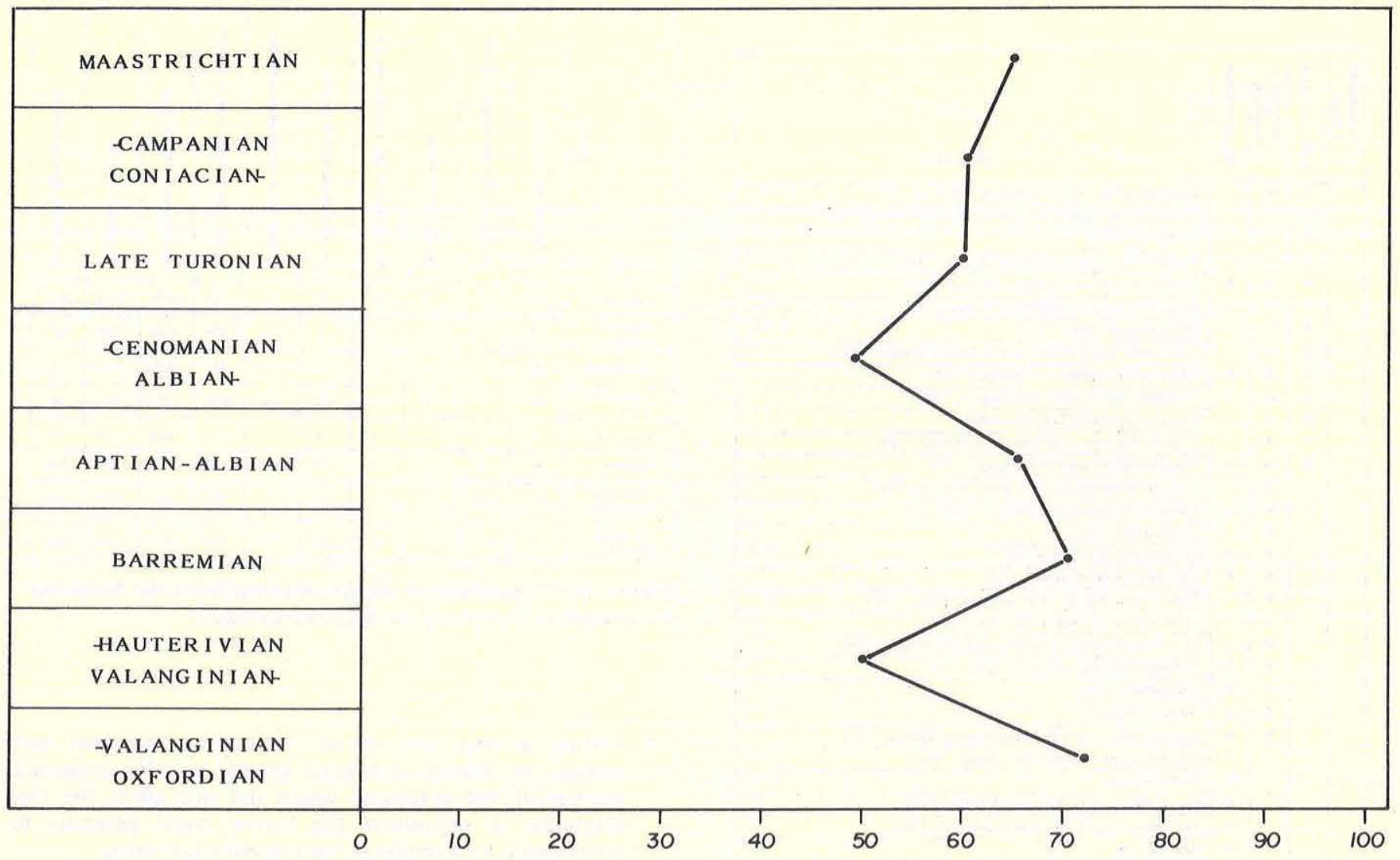

Figure 13 - Simpson Coefficient plotted values for the Magallanes Basin 


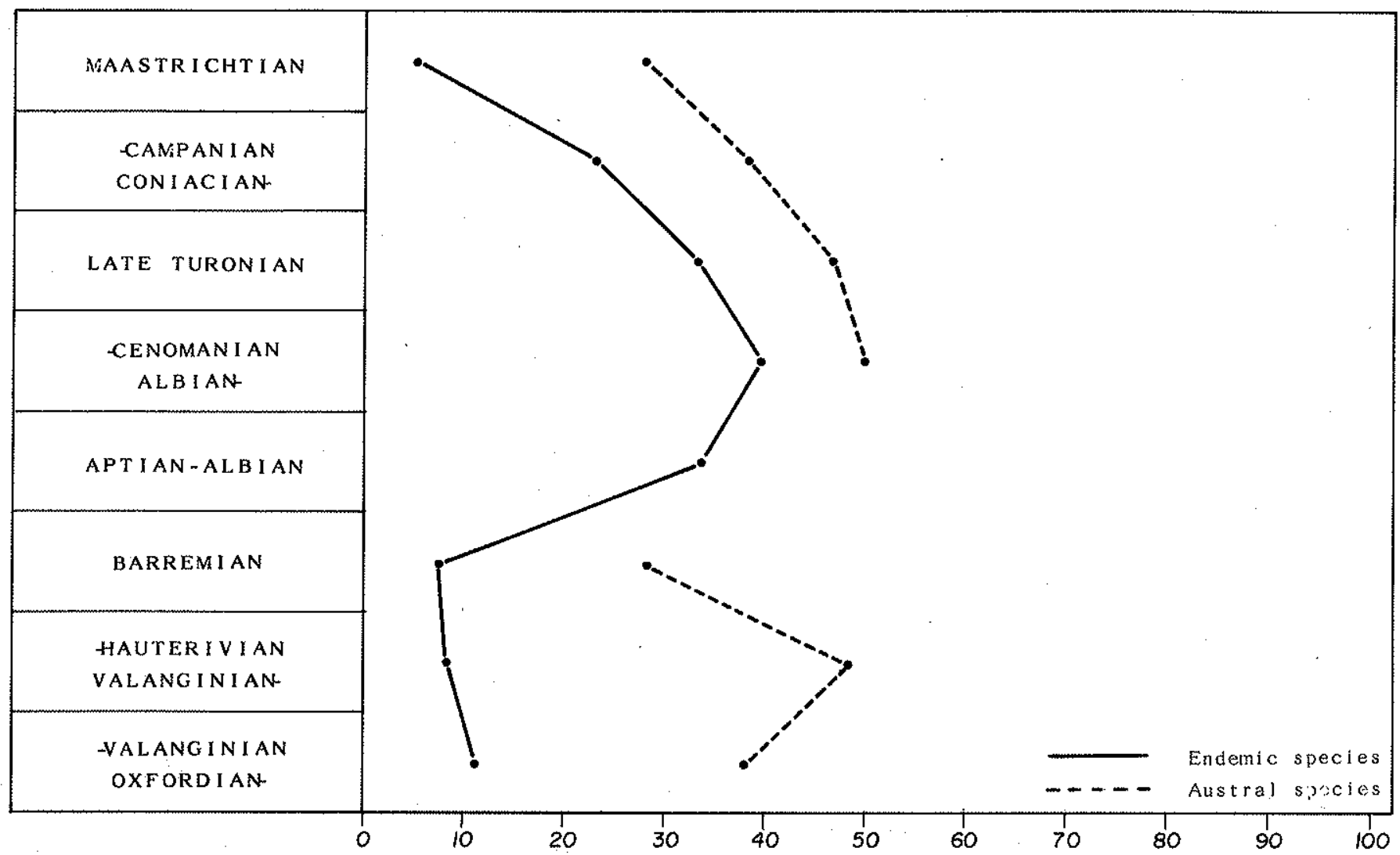

Figure 14-Percentage of endemic taxa of the Magallanes Basin

wide geographic distribution.

3. The Magallanes Basin microfauna show marked afromalgachian contributions whereas these are small in the Neuquén and Mendoza basins.

During the Maastrichtian, 55 valid species from the Neuquen and Mendoza (plus Colorado) basin were recorded; from the Magallanes Basin (42). Both have only three common species: Dorothia bulleta (Carsey), Bolivina incrassata Reuss, and Nonionella sp. cf. N. austinana Cushman.

The obtained provincial values are:

$$
\mathrm{PI}=0.04 \quad . \quad \mathrm{SC}=7.14
$$

which indicate a high provincial degree and substancial differences at the terminal Cretaceous. The feature induce to assume the restricted of null communication between both basins; in fact, the Rio Mayo-Río Chico-Punta Dúngenes hight (Urien et al. 1980) was practically an unsurmountable barrier for the benthonic Foraminifera interchange, beside other ecological factors, such as more marked thermal gradients; these in Late Cretaceous times probably acquired more importance, specially when compared with those of early Cretaceous, which could impede a similar behavoir in both basins.

CONCLUSIONS 1. Along the Cretaceous period, the Boreal, Tethyan, and Austral Realms are recognized; the Tethnyan based mainly on the participation in the associations of larger Foraminifera; the Austral based on the marked endemism of the assemblages of Madagáscar and Australia. At the end of the Cretaceous in the Tethyan Realm the Caribbean and Mediterranean regions become differenciated; 2. In Argentina, the Cretaceous biogeographic trends of the Neuquén and Mendoza basins (plus Colorado in Maastri- chtian time) and the Magallanes Basin assemblages show the following features: a. Neuquen and Mendoza (plus Colorado in Maastrichtian time) basins; a.l. Early Cretaceous (Berriasian-Barremian). Quantitative analysis demonstrate absence of provincial features. The assemblages have a wide geographic distribution being present species of the Boreal and Tethyan Realms; a.2. Late Cretaceous (Maastrichitian). It is characterized by the increase of endemic taxa and the preferentialy bipolar distribution of the community; b. Magallanes Basin; b.1. Early Cretaceous (Neocomian). It is peculiarized by the wide geographic distributed taxa and the participation of malgachian species: b.2. Aptian-Campanian. It is peculiarized by the relative large ammount of endemic taxa and the paulatine increase of Australian elements since Albian-Cenomanian times; b.3. Maastrichtian. It is distinguished by the presence of bipolar distributed species, the participation of Australian taxa, and the reduction of endemic species; 3. Comparison based on quantitative analysis between the assemblages present in the Neuquen and Mendoza (plus Colorado in Late Maastrichtian times) and the Magallanes basins reflect a marked provincial degree. It is : probable that during Early Cretaceous time a barrier, similar to the present Chile ridge, impeded a free migration. At Maastrichtian times, on the Atlantic margin, the Río Mayo-Río Chico-Punta Dúngenes hight could be responsible for the restricted to null interchange between both basins, beside some ecological factors such as somewhat stronger thermal gradients; 4. In Argentina, within the Austral Realm, the following palaeobiogeographic units are recognized: a. Neuquén and Mendoza basins (plus Colorado in Maastrichtian time); a.1. Neocomian $=$ Wide distributed or cosmopolitan association; a.2. Maastrichtian = Subprovince; b. Magallanes Basin; b.l. Neocomian = Subprovince to Endemic Center; b.2. Aptian-Campanian = Province; b.3. Maastrichtian $=$ Subprovince. 
BARTENSTEIN, H. 1952a. Taxonomische Revision und Nomenklator. In: HECHT, F.E. Standard-Gliederung der Nordwestdeutschen Unterkreide nach Foraminiferen (1938). Teil 1:Hauterive. Senckenbergiana, 33(1/3): 173-183.

BARTENSTEIN, H. 1952b. Taxonomische Revision und Nomenklator. In: HECHT, F.E. Standard-Gliederung der Nordwestdeutschen Unterkreide nach "Foraminiferen" (1938). Teil 2:Barrême. Senckenbergiana, 33(4/6):297-312.

BARTENSTEIN, H. 1962. Taxonomische Revision und Nomenklator. In: HECHT, F.E. Standard-Gliederung der Nordwest-deutschen Unterkreide nach "Foraminiferen" (1938). Teil 3:Apt. Senck. leth., 43(2):125-134.

BARTENSTEIN, H. 1965. Taxonomische Revision und Nomenklator. In: HECHT, F.E. Standard-Gliederung der Norwest-deutschen Unterkreide nach "Foraminiferen" (1938). Teil 4:A1b. Senck. leth., 46(4/6):327-366.

BARTENSTEIN, H.; BETTENSTAEDT, F.; BOLLI, H.M. 1957. Die Foraminiferen der Unterkreide von Trinidad B.W.I. Ecl. Geol. Helv., 50(1):5-67.

BARTENSTEIN, H.; BETTENSTAEDT, F.; BOLLI, H.M. 1966. Die Foraminiferen der Unterkreide von Trinidad. W. I. Zweiter Teil: Maridale-Formation (Typlokalität). Ecl. Geol. Helv., 59(1):129-177.

BARTENSTEIN, H. \& BOLLI, H.M. 1973. Die Foraminiferen der Unterkreide von Trinidad W.I. Dritter Teil. Maridal-formation (Co-Typlokalität). Ecl. Geol. Helv., 6(2):389-418.

BARTENSTEIN, H. \& BOLLI, H.M. 1977. The Foraminifera in the lower Cretaceous of Trinidad, W.I. Part 4: Cuche Formation, upper part: Leupoldina protuberans Zone. Ecl. Geol. Helv., 70(2):543-573.

BARTENSTEIN, H. \& BRAND, E. 1949. New genera of Foraminifera from the lower Cretaceous of Germany and England. J. Paleont., 23(6):669-672.

BARTENSTEIN, H. \& BRAND, E. 1951. Mikropaläontologische Untersuchungen zur Stratigraphie des nordwestdeutschen Valendis. Abh. senck. naturforsch. Ges., 485:239-336.

BARTENSTEIN, H. \& KAEVER, M. 1973. Die Unterkreide von Helgoland und ihre mikropaläontologische Gliederung. Senck. leth., 54(2/4):207-264.

BELFORD, D.J. 1960. Upper Cretaceous Foraminifera from the Toolonga calcilutite and Gingin chalk, western Australia. Bur. Min. Res. Geol. and Geophys., 57:1-198.

BERGGREN, W.A. \& PHILLIPS, J.D. 1971. Influence of continental drift on the distribution of the Tertiary benthonic Foraminifera in the Caribbean and Mediterranean regions. In: SYMP. GEOL. LIBYA. Beirut, 1971. Proceed... Beirut, Faculty of Science, University of Libya. Catholic Press, Beirut. p. 263-299.

BERTELS, A. 1972. Buliminacea y Cassidulinacea (Foraminiferida) guías del Cretácico superior (Maastrichtiano medio) y Terciario inferior (Daniano inferior) de la República Argentina. Rev. Esp. Micropaleont., IV(3):327-353.

BERTELS, A. 1980. Estratigrafia y foraminíferos (Protozoa) bentónicos del límite Cretácico-Terciarico en el área tipo de la Formación Jagüel, provincia del Neuquén, República Argentina. In: CONGR. ARGENT. PALEONTOL. BIOESTRATIGR. 2 y CONGR. LATINOAMERICANO PALEONTOL. 1. Buenos Aires, 1978. Actas... v. 2, p. 47-91.

BERTELS, A. 1986. Los foraminíferos del Cretácico de la República Argentina: sus tendencias paleobiogeográficas. An. Acad. Nac. Cs. Ex. Fis. y Nat. Argent., 38:265-305.

BETTENSTAEDT, F. 1952. Stratigraphisch wichtige Foraminiferen-Arten aus dem Barrême vorwiegend Nordwest-Deutschland. Senckenbergina, 33(4/6):263-295.

BROTZEN, F. 1936. Foraminiferen aus dem schwedischen, untersten Senon von Eriksdal in Schonen. Sver. Geol. Unders., Ser. C, 396(3):5-206.

CAN̂ON, A. \& ERNST, M. 1974. Magallanes Basin microfauna. In: NATLAND M.L., GONZALEZ, E.P.; CAÑON, A.; ERNST, M. A system of stages for correlation of Magallanes Basin sediments. Geol. Soc. Am. Mem., 139:1-125.

CARSEY, D.O. 1926. Foraminifera of the Cretaceous of Central Texas. Texas Bull., 2612:1-56.

CHAPMAN, F, 1891-1898. The Foraminifera of the Gault of Folkestone. J. Royal Microsc. Soc.,:1-758 (see foorote).

ESPITALIE, J. \& SIGAL, J. 1963. Contribution a l'études Foraminiferes (Micropaléntologie-Microstratigraphie) du Jurassique supérieur et du NÉocomien du bassin de Majunga (Madagascar) Ann, Géol. Madagascar, XXXII:1-100.

FLORES, M.A.; MALUMIAN, N.; MASIUK, V.; RIGGI, J.C. 1973. Estratigrafia cretácica del subsuelo de Tierra del Fuego. Rev, Geol. Argent., XXVII(4):407-437.

FRIZZELL, D.L. 1954. Handbook of Cretaceous Foraminifera of Texas. Bur. Econ. Geol. Univ. Kansas Rep. Invest., 22:1-232.

HECHT, F.E. 1938. Standard-Gliederung der Nordwest-deutschen
Unterkreide nach Foraminiferen. Abh. Senck. Naturforsch. Ges., 443:1-42.

JENNINGS, P.H. 1936. A microfauna from the Monmouth and basa Rancocas Groups of New Jersey. Bull. Am. Paleont., 23(78): 161-234.

JOHNSON, J.G. 1971. A quantitative approach to faunal province analysis. Am. J. Sci., 270:257-280.

KAUFFMAN, E.G. 1973. Cretaceous bivalvia. In: HALLAN, A. ed. Atlas of paleobigeography. Amsterdam, Elsevier, p. 353-383.

KIELBOWICZ, A. 1980. Estudio de la microfauna de sedimentitas del Cretácico superior en la zona de lago Pellegrini, provincia Río Negro. Buenos Aires, Fac: Cs. Ex. Fis. y Nat. Ciencias Geológicas (unpublished).

KIELBOWICZ de STACH, A. \& ANGELOZZI, G, 1984, Microfósiles calcáreos de la Formación Yacoraite en la subcuenca Lomas de Olmedo, provincia de Salta. In: CONGR. GEOL. ARGENT. 9, San Carlos de Bariloche, 1984. Actas... Buenos Aires. v. 4, p. $508-522$.

KIELBOWICZ, A.A.; RONCHI, D.I.; STACH, N.H. 1983. Foraminíferos y ostrácodos valangianos de la Formación Sprinhill, Patagonia Austral. Asoc. Geol. Argent., Rev., XXXVIII(3-4):313-339.

MALUMIAN, N. 1968. Foraminíferos del Cretácico superior y Terciario del subsuelo de la provincia de Santa Cruz, Argentina. Amegh. Rev. Asoc. Paleont. Argent., 7(6):191-227.

MALUMIAN, N.; MASIUK, V. RIGGI, J.C. 1971. Micropaleontología y sedimentología de la perforación SC-1 provincia Santa Cruz, Repúbliça Argentina. Rev. Asoc. Geol. Argent., XXVI(2):173-208.

MALUMIAN, N. \& MASIUK, V. 1975. Foraminíferos de la Formación Pampa Rincón (Cretácico inferior), Tierra del Fuego, Argentina. Rev. Esp. Micropaleont., VII(3):579-600.

MALUMIAN, N. \& MASIUK, V. 1977 (1976). Foraminíferos de la Formación Cabeza de León (Cretácico superior), Tierra del Fuego, República Argentina. Asoc. Geol. Argent. Rev., XXXI(3):180-202.

MALUMIAN, N. \& MASIUK, V. 1978. Foraminíferos planctónicos del Cretácico de Tierra del Fuego. Asoc. Geol. Argent. Rev., XXXIII(1):36-51.

MALUMIAN, N. \& NAN̄EZ, C. 1983. Foraminíferos de ambiente anóxico de la Formación Río Mayer (Cretácico inferior), provincia de Santa Cruz. Amghiniana, XX(3-4):367-393.

McLACHLAN, I.R.; McMILLAN, I.K.; BRENNER, P.W. 1976. Micropalaeontological study of the Cretaceous beds at Mbotyi and Mngazana, Transkei, South Africa. Trans. Geol. Soc. S. Afr., 79(3):321-340.

MENDEZ, J. \& VIVIERS, M.C. 1973. Estudio micropaleontológico de sedimentitas de la Formación Yacoraite (provincias de Salta y Jujuy). In: CONGR. GEOL, ARGENT., 5, Córdoba, 1973. Actas... Buenos Aires. v. 3, p. 467-470.

MUSACCHIO, E.A. 1979. Datos paleobiogeográficos de algunas asociaciones de foraminíferos, ostrácodos y carofitas del Jurásico medio y el Cretácico inferior de Argentina. Ameghiniana. Rev. Asoc, Paleont. Argent., XVI(3-4):247-271.

MUSACCHIO, E.A. 1980. Algunos microfósiles calcáreos marinos y continentales del Jurásico y el Cretácico inferior de la República Argentina. In: CONGR. ARGENT. PALEONT. BIOESTRATIG., 1, y CONGR. LATINOAMERICANO PALEONT., 1 (Simp. Límite Jurássico-Cretáceo) Actas... Buenos Aires. v. 5, p. 67-76.

MUSACCHIO, E.A. 1981. South American Jurassic and Cretaceous Foraminifera, Ostracoda and Charophyta of Andean and sub-Andean regions. Comité sudamericano del Jurásico y Cretácico. In: VOLKHEIMER, W. \& MUSACCHIO, E. eds. Cuencas sedimentarias del Jurásico y Cretácico de América del Sur. v. 2, p. 461-498.

NATLAND, M.L.; GONZALEZ, E.P.; CAÑON, A.; ERNST, M. 1974. A system of stages for correlation of Magallanes Basin sediments. Geol. Sc. Am. Mem., 139:1-125.

OLSSON, R. 1960. Foraminifera of Latest Cretaceous and Earliest Tertiary age in the New Jersey Coastal Plain. J. Paleont., 34(1): $1-58$

REUSS, A.E. 1862. Die Foraminiferen des norddeutschen Hils und Gault. Sitz.-Ber. math.-natur. K1. Kay. Akad. Wiss. Band, 46:1-100.

SCHEIBNEROVA, V. 1976. Cretaceous Foraminifera of the Great Australian Basin. Mem. Geol. Surv. New South Wales Paleont., 17: 1-264.

SCHEIBNEROVA, V. 1976. Cretaceous Foraminifera of the Great Australian Basin. Mem. Geol. Surv. New South Wales Paleont., 17:1-264.

SCHEIBNEROVA, V. 1978. Aptian-Albian benthic foraminifers of Leg 40, Sites 363 and 364, southern Atlantic. Initial Reports of the Deep Sea Drilling Project, 11.U.S. Government Printing Office, Washington, p. 741-756. 
SIGAL, J.; GREKOFF, N.; SINGH, N.P.; CAÑON, A.; ERNST, M. 1970. Sur l'âge et les affinites "gondwaniennes" de microfaunes (Foraminifêres et Ostracodes) malgaches, indiennes et chiliennes au sommet du Jurassique et à la base du Crétacé. C.R. Acad. Sc. Paris, 271:24-27.

SIMEONI, M. 1985. Foraminíferos del Cretácico inferior en los niveles basales de la Formación Agrio, Perfil El Marucho, Neuquén, Argentina. Ameghiniana, 21(2-4):285-293.

SIMPSON, G.C. 1943. Mammals and nature of continents. Am. J. Sci., 24:1-31.

SLITER, W.V. 1974. Cretaceous Foraminiferes from the southwestern Atlantic Ocean, Leg 36, Deep Sea Drilling Project. Initial Reports of the Deep Sea Drilling Project, 36. U.S. Government Printing Office, Washington, p. 519-573.
TEDFORD, R.H. 1974. Marsupials and the new paleogeography. In: ROSS, C.A. ed. Paleogeographic provinces and provinciality. p. 109-126.

URIEN, C.M.; ZAMBRANO, J.J.; MARTINS, L.R. 1981. The basins of south eastern South America (southern Brasil, Uruguay, and eastern Argentina) including the Malvinas plateau and southern south Atlantic Paleogeographic evolution. Comité Sudamericano del Jurásico y Cretácico. In: VOLKHEIMER, W. ed. Cuencas sedimentarias del Jurásico y Cretácico de América del Sur., v. 1. p. 45-125.

MANUSCRITO 498

Recebido em 24 de setembro de 1987 Revisão aceita em 04 de maio de 1988

* N.E. The referred papers from Chapman, F. (1891-1898) were reprinted by Antiquariaat Junk, De. R. Schierenberg \& Sons N.V., P.O. Box 5, Locher/Netherlards, 1970. The different parts that constitute the original work are as follows: Part I, 1891, p. 565-575; I, 1892, p. 319-330; III, 1892, p. 749-758 IV, 1893, p. 579-595 (Trans. of the Soc...); V, 1893, p. 153-163; VI, 1894, p. 421-427; VII, 1894, p. 645-654; VIII, 1895, p. 1-14; IX, 1896, p. 581-591; X, 1897, p. 1-49. 